\title{
BLACK ACTIVIST MOTHERING
}

\section{A H istorical Intersection of Race, G ender, and Class}

Katrina B ell M cD onald

The Johns H opkins U niversity

D epartment of Sociology

$540 \mathrm{M}$ ergenthaler $\mathrm{H}$ all

3400 N orth Charles Street

Baltimore, M aryland 21218

$410-515-7624$

e-mail: mcdon@jhu.edu 
Manuscript submitted for peer review. Do not copy or cite without expressed permission of author.

\title{
BLACK ACTIVIST MOTHERING: \\ A H istorical Intersection of Race, $\mathbf{G}$ ender, and Class
}

\begin{abstract}
The prevalence of poor health among young disadvantaged Black mothers and their children has prompted a revival of maternal activism among B lack middle-class urban women. A study of the California-based "Birthing P roject," founded in 1988, reveals that such activism is best understood as a modern-day version of B lack activist mothering practiced by A fricanA merican clubwomen from the time of slavery to the early 1940s. This article demonstrates the legacy of "normative empathy" as a significant motivator for middle-class maternal activism and as a basis for a middle-class critique of B lack mothering among the disadvantaged.
\end{abstract}




\section{BLACK ACTIVIST MOTHERING :}

\section{A H istorical Intersection of Race, $\mathbf{G}$ ender and Class}

F or more than 20 years, reformative social policy and technological advances have done little to curb the unyielding threat of Black infant mortality. Although the overall infant mortality rate in the U.S. has been on the decline for many years, recent figures show that B lack babies continue to die at more than twice the rate of those of whites (F ullilove 1993; Rowley et al. 1993; Singh and Yu 1995). This crisis, one of the most vexing problems for A frican America, was precipitated by a host of interrelated medical, sociodemographic, and psychosocial problems suffered primarily among the most vulnerable population: young African-A merican mothers of the "underclass" (B oone 1989; F ullilove 1993; R owley et al. 1993).

While the root cause of elevated poor pregnancy outcomes among African-A mericans lies in the historically oppressive conditions of Black women's lives, a popular argument is that this crisis, like many others, has been exacerbated by the restructuring of B lack social capital. The persistence of poor birth outcomes for B lacks is often linked to the recent "B lack flight" of the middle class from urban areas (Anderson 1990; B aca Zinn 1990; Wilson 1987, 1989). The

resultant spatial concentration of disorganized, unskilled, and alienated "underclass" populations in urban neighborhoods is said to worsen the most negative features of B lack mothers lives by effectively severing the long-standing link between B lack middle-class maternal support and disadvantaged women.

Claims about the significance of the social class schism in the B lack community are not 
easily dismissed. F or example, B lack feminist theory has addressed, though scantily, the class polarization of the B lack community and its potential to dismantle gender/ethnic solidarity. Some authors openly admit that the strong Black maternal activist tradition is not immune to the problems of urbanization and the dislocation of women from the "once familial" character of social relationships within the community (Ladner 1986, 17). As Collins explains,

The entire community structure of bloodmothers and othermothers is under assault in many inner-city neighborhoods, where the very fabric of African-A merican community life is being eroded $(1991,122)$.

$\mathrm{N}$ onetheless, while there has been a re-organization of social relations among African-A merican urban women, the exodus of middle-class women from urban areas has not necessarily resulted in an exodus of care, in the total removal of "an important 'social buffer' that could deflect the full impact of the kind of prolonged and increasing poverty that plagues [the inner city]" (Wilson 1987, 56). M odern Black activist women are concerned that the social degradation and isolation of young B lack mothers has led to the perception that B lack pregnancy and motherhood is not celebrated among the disadvantaged and that the Black community has failed to attend to the contemporary needs of A frican-A merican childbearing. They understand that social support that was common to B lack pregnancy and childbearing among the poor and working classes from which they came is uncommon for many mothers today; strong, cross-class maternal support -- at least in the form they call to memory -- is not characteristic of modern Black urban life.

In assessing the damage, Black middle-class maternal activists have sought to rescue 
disadvantaged mothers from their increasing social isolation. They have found it necessary to evoke a sense of gender/ethnic solidarity in creatively crossing class lines to positively affect B lack pregnancy outcomes. Their main objective is to exploit the empathy of upwardly mobile community women in order to re-create maternal support for the disadvantaged of the urban community and help thwart the escalation of poor pregnancy outcomes. Contemporary "new" middle-class (L andry 1987) B lack women believe that they possess a unique empathic motivation and ability to maintain ties with poor and working-class women. F urthermore, their strategy for intervention, born from a conscious, collective need to resist racist and sexist oppression, is one passed down for many generations by their B lack activist foremothers.

This article revolves around two main tasks. F irst, it seeks to highlight sociologically cross-class maternal support of urban Black women and to politicize the community mothering practices of those from the middle-class. My analysis of this tradition is guided by a theory- and data-driven framework, "normative empathy", constructed as a way of interpreting middle-class B lack maternalist motivations to maintain cross-class networks among B lack women in the $1980 \mathrm{~s}$ and 1990s. The data were drawn via intensive interviews with volunteers from "T he B irthing Project," an organization established to service the needs of young and poor B lack mothers. Second, this article argues that the struggle of B lack activist women to evoke a sense of cross-class gender/ethnic solidarity in the provision of maternal support stems from a long tradition of maternal activism among middleclass B lack women. O ne feature of this tradition has been the tailoring of activism to meet the needs of unique historical periods. Today, the women of the B irthing P roject must confront an epidemiological crisis of B lack childbearing qualitatively 
different from that which embattled the Black community 50 years ago. The dislocation of urban B lack women from one another has reached unimaginable new heights, resulting in an often difficult, frustrating struggle for gender/ethnic solidarity among the activist women. The research reported herein further elaborates a theory of social support (Cramer and M CD onald 1996) which helps to expose the often unforeseen and unanticipated political and practical problematics of such support. Specifically, this article examines the contours of maternal activism among middle-class Black women; the ideological precedent for this activism; and how the consciousness of social class difference shapes the middle-class B lack activist discourse and experience.

\section{NORMATIVE EMPATHY:}

\section{FRAMING BLACK ACTIVIST MOTHERING}

Social psychologists have identified two basic types of social helping behavior differentiated by the source of motivation. An actor, they contend, can be motivated to empathic helping behavior by a feeling for another's affective experiences; a personal, emotional response is summoned by a sense of connectedness to the condition of another person ( $\mathrm{H}$ enderson 1984; Wood 1994). The actor's empathy is apparently not necessarily thought to jeopardize the selflessness with which activism is carried out and, therefore, it is possible for activism to fulfill non-egoistic and egoistic needs. An actor can also be motivated to normative helping behavior by general social norms -- the moral and ethical principles generated by members of a community who share a common social history and vision for social development (M ontada and B ierhoff 1991). This distinction between types of activism and their motivation, however, fails to capture the unique and historically-driven experiences that have fed the B lack activist mothering 
tradition.

The analyses of B lack women's maternal activism conducted for this study suggest that "normative empathy," a synthesis of both personal and social motivation, is a more appropriate framework for analyzing the community mothering practices of A frican-A merican women. B lack women's activist motivations derive from a conjunction of empathy for other B lack women who suffer or have suffered similar social disadvantage and of A frican-A merican norms of solidarity, responsibility, and accountability. That this moral obligation to enhance gender/ethnic survival inherently has egoistic as well as other-oriented bases demonstrates that existing frameworks for interpreting their activism are too simplistic for a full appreciation of this tradition.

Scholarship on Black women's social history is laced with references to B lack women as important intergenerational resources in the African-A merican community (Christian 1985; Collins 1991; DuB ois 1939; Giddings 1984; G ilkes 1989; M CD onald 1995; Rodgers-Rose 1980; Sudarkasa 1988; Joseph and Lewis 1981). A ccording to G iddings, educator and clubwoman Julia Cooper identified the special role of women's activism as "the fundamental agency under God in the regeneration... of the race, as well as the groundwork and starting point of its progress upward" $(1984,81)$. F rom a very young age, Black women are reportedly socialized to yield to the call of responsibility to "hold the Black community together" (Joseph and Lewis 1981, 106) and preserve the race and gender.

Central to the sociological framing of B lack women's community activism is a unique gender/ethnic motivation. B lack women's gender identities help distinguish their motivations for social activism from that of Black men; their community activism is driven by their shared, 
gendered experience of slavery and has developed primarily out their mothering practices (J ones 1990). F urthermore, B lack women's motivations for activism are distinguishable from white women's motivations. Their unique race/gender status has strongly influenced how they define family and community and how they determine which political strategies are best suited to meet the needs of B lack women, their families, and the race as a whole (G ilkes 1988; $\mathrm{H}$ ine 1990; M orgen 1988; M orgen and B ookman 1988; $N$ aples 1991 and 1992). This norm of solidarity and collective survival through community mothering practices has been characterized as Black "activist mothering" (N aples 1992) or community "othermothering", ${ }^{1}$ a transplantation of traditional A frican tribal principles (Peterson 1992). The community work of B lack women, like that of other women of color, is a complex practice of biological mothering, community othermothering, and political activism ( $\mathrm{N}$ aples 1992).

$\mathrm{N}$ ormative empathy also emphasizes the significance of social class in politicizing the task of B lack women to serve their community. It is frequently noted that middle-class status compounds B lack women's sense of "social debt" to the community (H igginbotham and W eber 1992, 430; M CD onald 1995; N aples 1992). The "races as families" analogy promoted by the "race school" of sociology for decades, and founded upon the philosophies of W.E.B. Du B ois and B ooker T. Washington (D awson 1994), strongly elevates race obligations over those of class. Individual women of the middle class are said to be held "morally culpable" (L awson 1992, 94) if they do not live up to the expectation that successful B lack women should help their less fortunate "sisters. E very woman's middle-class success story must also be a tale of how she fulfilled her moral obligation to uplift others of the race less fortunate than she (Collins 1991; D awson 1994). 
The analyses of H igginbotham (1993) and B oris (1993) speak instead to an intersection of social class and B lack activism that produces a variety of maternal activist strategies operating at different levels of class and reflecting varying, class-based expressions of normative empathy. $\mathrm{N}$ ormative empathy appears more likely to find expression among the middle class as an obligation and duty to the disadvantaged; by virtue of belief in their superior moral upbringing middle-class women would be inclined to teach lower-class women to be more like themselves. N ormative empathy among middle-class women serves not only as motivation for social activism but also as a basis for critiquing the mothering practices of the disadvantaged.

F ar less attention is paid to how class intersects with the community practices of disadvantaged Black women. While it could be understood that their access to fewer material resources would place restrictions on what poor B lack women offer as community othermothers, the historical literature suggests that their reverence for and political commitment to solidarity is no less than that of their middle-class counterparts. In contrast to that among the middle class, normative empathy among the disadvantaged appears more likely to be formed from a view of all B lack women and mothers as the source of uplift and to take the form of intra-class social support.

Additionally, the practice of normative empathy is temporally sensitive to the conditions of B lack women's lives. The form and content of Black activist mothering have changed somewhat with the increasing polarization of B lack social classes. As the problems suffered by the most disadvantaged women of the community worsen, middle-class B lack activists step up their efforts to lift them up, and perhaps in doing so overshadow the maternal activism still operating among 
the disadvantaged and focus a biased lens on the mothering practices of poorer Black women.

This study seeks to understand the motivations of the B irthing P roject volunteers who are overwhelmingly middle class. No data were collected from disadvantaged populations or about them other than that which is offered from the perspective of the middle class and, therefore, this particular study does not speak to the experience of being the recipient of middle-class maternal care. It demonstrates how strongly middle-class B lack women cling to the legacy of their foremothers and to a middle-class display of normative empathy.

\section{THE BIRTHING PROJECT: RE-CREATING MATERNAL SUPPORT}

The research site for the observation of contemporary, middle-class B lack maternal activism was "T he B irthing P roject," a volunteer organization founded in S acramento, California in 1988. The Project grew out of a resurgence of A frican-A merican women activist groups after their decline and suppression around the late 1940s (G iddings 1984), a decline that may have reflected the A frican-A merican intelligentsia's failure to embrace the broad spectrum of racial uplift efforts in the Black community (Gaines 1996). A recent survey of 22 Black women leaders representing eleven different African-A merican voluntary associations revealed that today there are many formal and informal Black organizations that claim to provide moderate or extensive support to Black women (Dickerson 1994).

F ounded by Kathryn $\mathrm{H}$ all, a health administrator, the B irthing Project offers the opportunity for young pregnant African-A merican women at risk for low birthweight and infant mortality to increase their chances for delivering healthy B lack babies. It strives to recreate 
informal social support lacking or nonexistent for many young mothers and to do so in the spirit of their activist foremothers. E arly B lack clubwomen were well known for having been instrumental in laying a B lack communal infrastructure to "re-create the intimacy of village life they left behind" (M athews 1992, 192).

In 1985, H all became agitated by the statistical data circulated within the state health office where she worked which showed that the mortality rate for B lack infants (age one and younger) in California was 16 per 1000 births; the rate for whites was 9 per 1000. Paralleling these statistics were the related figures on low birthweight, an equally disturbing phenomenon. $\mathrm{H}$ all's experience in state health administration made her keenly aware of the limitations of maternal health and family research and policies in removing this peril from the AfricanAmerican community. F requently, state and federal administrators concluded that the problem was related to the poor "viability of black genes"; therefore, nothing, they said, could be done to lessen the racial disparity. $\mathrm{H}$ all, who had herself lost a child that she believed could have been saved with proper medical care, was understandably infuriated by this racist analysis, and she set out to warn the B lack community of the widespread adoption of this perspective in the health community. Little assistance could be expected from within the official maternal health infrastructure; as earlier reformers had put it, the B lack community had to be told not to wait for the deliverers (Gordon, 1994).

$\mathrm{H}$ all explains that the mission of the Project is "to catch a [B lack] baby and pay witness to the birth." The Project reestablishes a collective of witnesses to B lack births in order to legitimate the children's existence and to ensure that elder women will be there to give them 
guidance. $^{2}$ The Project relies on the willingness of middle-class "sister-friends" to offer intimate, informal social support to underprivileged young expectant mothers during their pregnancies and for a year or more postpartum. I ts founders were confident that the capacity of activist women -upwardly mobile women from poor and working-class backgrounds -- to restore gender/ethnic solidarity across class could assist underprivileged young urban mothers and, in particular, reduce the severe risks to maternal health faced by this population.

$\mathrm{H}$ all put out a call to "the ten toughest sisters" in the Sacramento area to work with her in combating the black infant mortality problem from within the Black community. E ventually, nine women (and one man) formed the original founding "sister-friends (and "brother-friend") for the P roject. Together, this group devised a plan to secure the future of the B lack family and B lack culture. They sought to utilize the maternal gifts of B lack women by exploiting the resources and resourcefulness of middle-class women who were better situated socioeconomically to tend to the maternal needs of other A frican-A merican families and who could relate to the social disadvantage suffered in those families.

As is true for most charismatic founders of community organizations, $\mathrm{H}$ all personifies the Project's ideals. H er word and tone are almost theological, resonating with that of many of her famous foremothers like M ary Church Terrell, who once proclaimed that B lack women's "peculiar status in this country" called them to "the great firm of progress and reform." ${ }^{3} \mathrm{H}$ all's concern for the witnessing of a child's birth, literally and figuratively speaking, is a concrete demonstration of what Collins (1991) contends is a B lack feminist "ethic of caring:"

$\mathrm{N}$ urturing children in the Black extended family networks stimulates a more 
generalized ethic of caring and personal accountability among African-A merican

women who often feel accountable to all the Black community's children (129).

It is familiar folk talk among A frican-A mericans that it used to be such that anyone witnessing a child's birth (i.e. either being attentive to the mother around the time of the pregnancy, physically present at the birth, or involved in some way with the christening/blessing) assumed the right later in that child's life to intervene in any way he or she felt was appropriate, $\mathrm{H}$ all explains. This included rightfully disciplining the child when necessary, thereby showing community love and concern. Community members of all social class backgrounds accepted and desired this intervention and saw it as a natural extension of the family.

When there are no witnesses to a marriage the union is not valid; when there are no witnesses to a baptism one's salvation is not recognized by that church. Thus, $\mathrm{H}$ all argues by analogy that when the only onlookers to a B lack baby's birth are its mother, an impersonal county hospital staff, and perhaps a social worker or a prison guard, that child's life goes largely unattended. $\mathrm{H}$ all feels strongly that by re-creating much needed maternal support in the African-A merican community, the B irthing P roject re-establishes an inter-class collective of witnesses to Black births in order to legitimate the children's existence and to ensure that elder and more socioeconomically stable women will be available to give them guidance.

Prospective sister-friends are introduced to the P roject first through printed media, through a public presentation by $\mathrm{H}$ all, or through word of mouth. The formal introduction is made when the volunteer attends one of the official training sessions typically managed by the Project's chief administrator. Training sessions primarily are meant to instruct the volunteer to 
regularly convey the importance of prenatal care to her "little sister," ${ }^{\prime 4}$ to suggest ways to assist tangibly in her prenatal care, such as providing her transportation to medical appointments, and to emphasize the need for the volunteer to be readily available to assist her little sister in any other way she could, such as providing her referrals to other agencies for information and support. In the extreme, the volunteer is told, one could be called upon by the P roject to intervene on the little sister's behalf should an authority's action (e.g. social worker, judge, teacher) pose a potential threat to the healthy progress of the pregnancy or to the little sister's personal development overall.

D uring these sessions volunteers are also informed about ways to minimize the stress involved in befriending the little sisters. The limitations of what they should do in their relationships, such as to not lend money, and of what the P roject can reasonably accomplish is explained in detail. These sessions were re-designed somewhat in the early 1990 s to accommodate the volunteers' need to better understand the nature of the social class tensions that was likely to emerge.

The training sessions are not only useful for dispensing practical materials and information, they are often one of the few opportunities, if not the only opportunity, for the administration to transmit the overall mission of the Project and its norms and values to the sister-friends. In some cases, however, volunteers by-pass the training session to help meet the overwhelming, immediate need to service prospective little sisters. Still, the Project estimates that 100 trained sister-friends were active each year, ${ }^{5}$ probably fewer in the first five years.

Although the Project is most frequently referred to as a mentoring program, its social service is better understood as one that provides young mothers a personal confidant. The sister- 
friends opt for a more meaningful, reciprocal, personal relationship with the little sisters that, though ultimately intended to help ensure an uneventful pregnancy and birth, is shaped by the unique personal and social circumstances of both the young mothers and the volunteers. In sum, this relationship is intended to extend the kinship bonds and networks of both parties and to politically empower all members of the community.

The Birthing P roject is but one component of a larger self-help effort by community women to supplement government agency programs or to provide services nonexistent in Sacramento C ounty. This multifaceted enterprise addresses a wide range of social and political issues, revealing a Black feminist vision of welfare akin to B lack women and other women activists of an earlier era (Gordon 1994; $\mathrm{H}$ amilton 1978; $\mathrm{H}$ arley and Terborg-Penn 1978; Jenkins 1984; Lerner 1974; N everdon-M orton 1989; T ownes 1993). U nder the umbrella of the Center for Community H ealth and W ell-B eing, Inc., are parallel programs: "Imani", which provides support to women who engaged in or who are potentially at risk for child abuse and/or substance abuse; the E conomic D evelopment Program, which trains and employs women to provide in-home support services to families; and the Comprehensive P erinatal S ervices P rogram, which offers maternal health care. The B irthing P roject is acknowledged as the heart and soul of the Center, and in 1993 it became B irthing P roject U SA with its program replicated in 15 cities around the country. A program module produced by $\mathrm{H}$ all has been used by social service agencies across the nation as well. B etween 1988 and 1997, Project-related programs were established in 48 U .S. cities and one Canadian city; thirty of these program remain active. 


\section{DATA COLLECTION}

The primary data collection I method used at the B irthing Project was intensive interviewing of 19 of these sister-friends in 1993. E ach of these women served as a sister-friend one or more times since the organization's inception and were selected from virtually the full population of African-A merican sister-friends who had ever served at the P roject.

Limited operating funds and personnel made it difficult over the years for the small staff at the P roject to keep good, reliable records on each volunteer; age, level of education, occupational, marital, and maternal status were not recorded consistently. Though it was impossible to construct an accurate demographic profile of the sister-friends, I made a deliberate attempt to derive a study sample of 40 volunteers that cross-cut each of the sister-friend cohorts. Of the 90 women who could be identified as sister-friends, approximately 50 percent could not be reached due to insufficient or missing contact information.

Of those sister-friends who could be reached, ultimately 19 responded favorably to the invitation and completed the interview. They range in age from 17 to 61 . F our were married, five divorced, one widowed, and eight had never married. O nly two had no college experience (one, a 17-year old high school student), one possessed a law degree, and another was pursuing a doctorate. $\mathrm{N}$ ine of the women were employed in administrative staff positions with the $\mathrm{S}$ tate of California, three were college students, one was a postal worker, and five others were clerical workers or homemakers. Thirteen had biological children. With the exception of the four students, these women were either explicit or implicit in stating that their social status had once been as precarious as many of the little sisters. Sister-friend Pam (age fortysomething) summa- 
rizes the latter point well:

I can see myself in those women. They can feel that; they know that I can relate to what they're going through, because a lot of what they're going through, I have been there.

An unstructured, open-ended interview guide was developed for this portion of the research, and the interviews lasted for one to two hours usually in the woman's home. The names of the respondents have been changed to protect their privacy. In addition to the interviews, I took field notes periodically at the Project from 1991-1994. I met with the organization's founder and chief office manager and visited the administrative office where a variety of everyday Project activities are undertaken. A collection of numerous published materials on the Project secured from sources on and off the site were also reviewed.

Post-World War II "Black middle-class" women are generally defined as those who work in white-collar occupations, who have higher than average levels of education, an annual income equal or greater than the median income for whites (D awson 1994; F eagin and Sikes 1994; Wilson 1980), a community reputation based on their socioeconomic achievement (B enjamin 1991), and a lifestyle that reflects their relative economic and political power as community leaders (D awson 1994). In light of this, I am comfortable classifying each of the sister-friends in the sample as middle class.

Secondary literature sources were consulted to help trace the history of middle-class B lack maternalist activities. B lack activist women of the late 19th and early twentieth centuries formalized their activist roles in establishing a nationwide self-help agenda to advance and uplift 
Black womanhood and Black families from racist and sexist subordination, and to redefine B lack motherhood as a political as well as a cultural strategy (B oris 1993; Shaw 1991). Documented evidence traces the formal expressions of B lack maternal activism the Black Women's Club Movement to at least 1793, though its informal expression was observed earlier among female slaves and freewomen. ${ }^{6}$

$\mathrm{N}$ one of those interviewed at the B irthing P roject identified the organization as middle class; rather, the P roject was referred to simply as a B lack, B lack women's, or B lack (or A fricanAmerican) community organization. N oteworthy, though, is the fact that the founders and those since recruited were from the new crop of middle-class A frican-A mericans and share many of the same social characteristics as the B lack clubwomen who preceded them and also engaged in maternalist activities.

\section{THE LEGACY OF NORMATIVE EMPATHY}

\section{AT THE BIRTHING PROJECT}

[T he P roject's founder and I ] both have a passion and interest in the African-A merican community, particularly women, the strength, the ties that bind involvement, the burden, responsibility we take and share... for ourselves and for our kids, no matter who gave birth to them. They're all ours.

-- sister-friend Loretta

Motivations

B lack maternal activism in the present day is ideologically grounded in a tradition begun 
by free, slave, and later newly emancipated B lack women (Christian 1985; Collins 1991; M artin and $\mathrm{M}$ artin 1985; Sudarkasa 1988). $\mathrm{H}$ alf a century ago, Black clubwomen were challenged by the devastating poverty and pervasive health problems that plagued the B lack community after Reconstruction as its population became more physically mobile and scattered between the $\mathrm{N}$ orth and the S outh (Jones 1985). In recent decades, the urban dislocation of many A frican Americans from middle-class support has intensified. As Pam, a sister-friend, notes, "B efore, we had the extended families. And with the moving around - people moving around - we don't have the extended families anymore."

A sense of gender/ethnic consciousness that once fueled widespread political and social cooperation and support among B lacks has been largely supplanted by individualism, mistrust, and competition as strategies for survival in the cities (Anderson 1990). The breeding of these alternative strategies has paralleled the increasing disparity of urban social resources and life chances. Government intervention for poor inner-city Blacks has been implicated, though poorly supported empirically, as a contributor to the undermining of normative empathy in the Black community (M artin and M artin 1985).

In response to the harsh realities of contemporary urban A merica, middle-class B lack activist women like those at the Birthing P roject have stepped up their efforts to preserve the race and ensure healthy, productive lives for B lack mothers and children of all social classes (Dickerson 1994). S peaking on behalf of herself and other founding sister-friends at the B irthing P roject, Loretta - a 38-year old state worker who provided one of the most detailed interviews in the collection - describes the motivational rationale for joining in the recreation of maternal support, 
highlighting the obligation of the Project to revitalize the community structure of female extended kin:

What we wanted to do then was to have some demonstrable impact on the lives of these young people in terms of how we were raised and how we grew up. We all came from varying backgrounds... but there were certain commonalities within that, particularly our pride in ourselves, our ties with A frican history, our respect for B lack family, for other adults, certain key things we felt these young people were losing. It was transferred right. They didn't have the advantages of sitting at grandmother's knee or talking to their mothers and having these things transferred to them orally or in terms of how they were told to conduct their lives because parentage just wasn't going on the way it normally did in Black families; they just weren't staying together. So we really wanted to disrupt this new pattern that was taking hold of our young people...we wanted to try and re-instill those traditional values that were so important to us and to our success and that we felt was a key to the success of any person, but A frican American young women in particular. Like most of the other sister-friends, Sylvia, age 48 , believed that offering herself as a living example of success and self-actualization attained despite the odds was invaluable to the little sisters. "Role modeling", she explains, imparts power to disenfranchised young mothers and is significant to fulfilling one's middle-class obligation to help uplift them to safer ground.

The sister-friends of this study furnish ample evidence of a recycling of feminist support among female family members generally in times of crisis. M oreover, they believe that their 
Project activities are reminiscent of the type of maternal care they had once received from their own mothers and othermothers. Their desire to oblige the tradition of othermothering, to give something back to the community now that they were upwardly mobile, often stems back to a particular, significant act of caring. F or example Charlie, a 37-year old state worker, spoke of her admiration for her "strong mother," a woman who transmitted the objectives of activist mothering through her courage and persistence in raising eight well-educated children on very few material resources:

I just thought that I had learned a lot from my mother in terms of survival, in terms of values and rewards and all of that, [that] I could share. Joyce and Janice had similar recollections. Joyce is a 22-year old college student and Janet is a divorced mother and grandmother employed with the state:

Joyce: Just looking back at all the help I got [from my mother and others] when I was pregnant...I thought that somebody else might need the same type of support that I had. I was willing, you know.

Janice: M y mother is my role model; my mother is a good role model... we're best friends so I've never had a problem. I've always had a good support system throughout my whole life...

Activist mothering at the B irthing P roject is fueled by personal histories of racist and/or sexist oppression that the volunteers use to help make the initial connection with their little sisters. The concrete experiences of confronting racist and sexist individuals and institutions 
informs the sister-friends' views about the need for strong maternal guidance of young B lack women. Tales of the moments when Black womanhood was challenged, undermined, and distorted were recalled by the sister-friends. The dialectical relationship of oppression and activism reflected in such tales were occasionally offered as a partial cause for choosing the B irthing P roject as an avenue for educating young mothers about the need to demand respect for themselves and their families. F or example, D oris, a 43-year old divorced mother, had this tale to offer:

[I'Il tell you] what I said to brothers when I do workshops, I say, "You know, brothers, only problem I have is you cannot adopt the rules of the slave master when you have been part of the game. H ow can you inflict on me the same sets of standards and rules that he inflicted on me and his women when you are not part of the system. He has so little respect and regard for you, how can you turn around and be a part of his group? And you know you're not of his group." And they say to me, "Cause [you] had and can't do this, and you women need to know your place." And I say, "W hat place? What place? What is my place? H ow dare you!"

Karen's story is equally powerful in pointing to the significance to her of sisterly intervention made by a non-B lack political ally. Karen is a 61 -year old public servant seeking a doctorate in theology:

... I went to [the local community college] four times before they would take me because I didn't have enough education. They said, 'O h, you'd never make it nursing'... [T he registrar] said that she couldn't take me because I had five children 
and I didn't have anybody to help me with them and I would miss too many days out of school... So I went and told my neighbor (M iss Trula) who was a white lady [and] she said, "Why don't you tell her she [a] prejudice SO B and get it over with." And I said, "I t's late and she just didn't have room for me." She said, "Watch my smoke"... So [later] I went back in and told [the admissions officer], I said, "You just took my neighbor and you told me that you didn't have any space." She said, "I forgot you were on the waiting list, Karen." I said, "It's obvious that you don't want me in the program." ... She said, "You? You couldn't be no RN ...I tell you what. If you can get your books and your uniform and get in here by M onday I'II take you." I didn't have a penny. I had ridden over there with her (M iss Trula).

So I was dignified and I told M iss Trula and she bought my uniform, bought me a watch, bought my books, and she said, "Go tell her you'll be ready."

Testimonies of success and support like this form the crux of the sister-friend component of the B irthing Project in that they portray hope in a world potentially debilitating for young expectant mothers who will undoubtedly meet with similar situations. They confirm that the sister-friends are determined to see that the young B lack women they seek to support will also be successful despite their adversaries. Potentially, these stories are what draw young mothers to the Project and what facilitates trust between the two parties of the maternal friendship.

\section{Education as a P rimary Goal}

In addition to highly valuing cross-class gender/ethnic solidarity, putting B lack mothers in contact with educational institutions (what H igginbotham calls "assimilating apparatuses" (1993, 
28)) has always been related to "a very pragmatic concern [among activist women] about the relationship among training, the purity of the home, and economic survival" $(1984,101)$. A bout one-half of the volunteer women interviewed for this study made some mention of their concern for, or assistance with, their little sister's education. Julie, a fortysomething divorced mother of two adult children, said that the biggest concern for her 16-year old little sister was getting her back in school after having dropped out. Charlie would frequently "go over and help the kids [of one little sister] with their reading lessons" and made a point of "exposing" another little sister to things that would help her "be aware of how intelligent she is and realize that she has a lot to offer."

Joyce was adamant about her little sister's right to a good education:

... she talked about going to college and she was talking about how the counselors are at school, how they don't encourage the B lacks to go school or to take college prep courses or anything like that. And I told her to demand, make sure you are put in college prep courses because it you're not then you will not get into college. While their educational backgrounds no doubt made the sister-friends good role models, it was not clear from the interviews how much the little sisters knew about the volunteers' educational accomplishments; this was not a subject systemically covered in the interview. $\mathrm{N}$ onetheless, like their foremothers, the middle-class women of the Birthing P roject see educational advancement as the key vehicle for helping young B lack urban mothers avoid the abyss of inner-city life. 


\section{The Issue of Social Class}

I've had my car vandalized. I've been called out of my name [spoken to vulgarly]. These are not my people. I've never been afraid of my people, but I'm intimidated with the people who are over here with their gang (implying "low class") mentality. I want to say, "Y ou don't know how much I love B lack people." They don't care because the don't have a sense of community.

- sister-friend Charlie

W orking to transcend social differences is the proud centerpiece of traditional Black women's community activism. E arly clubwomen fervently promoted the principle of mutual respect for all B lack women who, regardless of the quality of their personal and social attributes, were equally deserving of the opportunity to move forward (B oris 1993; H igginbotham 19937). According to G iddings $(1984,98)$, "In many instances, the lessons of their own lives had taught them that it was opportunity and environment - not circumstances of birth or previous experience - that separated them from the masses."

E ven as they sought to maintain a gender/ethnic solidarity across class, however, many believed that the "moral recovery" (B oris 1993, 226) of disadvantaged B lack women from their social condition was the primary substance of Black maternal activism.

Similarly, while normative empathy and middle-class obligation provide the political motivation for combating oppressive social forces that have contributed to the contemporary urban crisis, they also frequently call upon the middle-class sister-friends to take a moral stand against what they see as self-defeating values and behaviors exhibited by some members of the 
little sisters. Their willingness to condemn personal irresponsibility among the young mothers has added to the tension between the parties, as has been the case among classes of A frican-A mericans in the community at large (L awson 1993). H ence, the maternal activists at the Project are not immune to the interpersonal effects of the increasing social dislocation of many young B lack mothers in the inner-city, and their testimonies help to illustrate the complex ways in which the activists struggle to maintain their commitment to racial uplift in the midst of a deepening class schism in the Black community.

Extensive community and family involvement is common among B lack middle-class women who typically view this as part of a strategy for maintaining a certain detachment from the demands of their professions and a strong attachment to the Black community and its interests (G ilkes 1983). N evertheless, the busyness of this middle-class lifestyle is a major contributor to a heightened awareness of difference between the women. V anessa, a 39-year old university employee, explained that she simply could not preserve enough energy to give to yet another person at the end of the day:

It was too much for me to be going to school, to be working 40 hours, [taking] care of my mom, and trying to deal with "the smoker"...U ntil I could drop two of the items that I had, I just called it quits...

Though she clearly recognized the potential negative consequences of an overburdened community life, Charlie failed to adequately protect herself from extreme emotional and physical burn-out. F actoring in other issues, like the time it took to commute to and from home and to paid and unpaid work sites, was also a challenge for several of the sister-friends. Janice, for 
instance, commuted about 3-4 hours round-trip to work everyday which made it virtually impossible to see her little sister during the week or to attend any of the group functions held at the P roject. In sum, time constraints posed by the multiple career and social obligations of these middle-class sister-friends appear to have created at least some of the reported tension between the women and may have resulted in lost opportunities to bridge social differences within the dyad. O f particular note is the fact that only 5 of the sister-friends said that they were able to be present when their little sisters gave birth.

According to the sister-friends, tension was also a consequence of the little sisters' perceptions of at least some of them as different, presumably because of their inexperience with living on "the street" and of their being materially well off. Rachel (a 26-year-old widow), for instance, found that she had to convince her little sister that she was not a "snob": "you don't know, I come from the same background [as you do]. It's just I got out of it; I was one of the lucky ones."

Some of the little sisters thought it was "strange," as D oris puts it, that middle-class women would go to such lengths to help them and not expect anything materially in return; they didn't know whether they should fully trust the volunteers or whether they themselves could ever be seen as fully trustworthy. D oris' own little sister once said to her, "You know, you don't have to do this. N obody's paying you to do this."

The little sisters generally believed the volunteers were naive about how disadvantaged young women like themselves adapt to their oppression by learning to exploit social relationships. Pam, whose administrative position at the P roject made her privy to the perceptions of both 
parties, thought the young mothers' opinions on this matter were well founded:

I think [it's] what you call a socioeconomic background [that] makes a difference. People who have been sheltered all their lives, what you call "do gooders" ... want to do things for people, but they don't understand what is going on in the life of a woman who has had to struggle and maybe had to do things that were illegal or immoral, but they had to do them to survive. People wouldn't be expected to understand that.

Limited knowledge of these survival skills may have been the basis of complaints by some of the volunteers about their little sisters' needs being too great. The seriousness of the young mothers' problems was in many instances severely underestimated:

B eatrice (25-year-old college student): I went into [this] not knowing, you know, how needy she was or what it was that she needed. And come to find out she's very needy, and I don't know that I 've been there in every way that I could have been for her, but I did what I could.

Phyllis (44-year-old postal worker): The reason that it didn't work out for me with her was I felt she was too dependent, too needy. She wanted me almost as a financier and she was more dependent on me that I wanted in our relationship...there were just some things that seemed to be going on that I just didn't want to get involved with.

V olunteers expressed that they grew weary of what they characterized as deceitful, 
"street-wise" ways in which some young mothers sought sympathy and material goods from their sister-friends. Pam implied that the tools of such deception are sharpened on "the street" and the behavior is reinforced each time it yields the rewards the young mothers seek. As Anderson's research (1990) reveals, "street wisdom is largely a state of mind" developed and refined as one negotiates the uncertainty of urban life (5); to be "streetwise" is to understand "how to behave" in uncertain social spaces (6). $\mathrm{H}$ is analysis suggests that the sister-friends who were confronted with unanticipated expectations should not expect that their show of committed friendship and sisterhood will eliminate the young mother's feelings of mistrust, nor preclude the mother from employing tools of deceit to maximize the benefits she could receive from the maternal support relationship.

Closely related to their frustration with alleged deceit and manipulation is the sister-friends' displeasure with the young mothers' opportunism. The volunteers spoke frequently about the tendency of the young mothers to "take as much as they could" while the getting was good. B ecause the little sisters have so few resources of their own and because they know so little about how to obtain those resources, they at times lean heavily on their sister-friends for things they truly need as well as for things the sister-friends do not believe are necessary. At one point, V anessa clearly felt that her little sister had gone over the line when, after the sister-friend agreed to take the mother shopping for baby clothes, the mother suggested that the next time they should include her biological sister and travel to another city where the "shops are better."

Displeasure about the little sisters' materialism and opportunism - particularly when it was overt - eventually turned into resentment in some instances. Their behavior fostered negative 
impressions among the sister-friends about the young mothers' sincerity in developing a meaningful, quality support system based on more than material gain. L oretta's assessment of this particular dilemma is a good summary of the kinds of negative sentiments expressed: ...the young lady I got was a real opportunist. She came in thinking that she'd get in this project and I would be her taxi and I would be her benefactor and I would take her out and do all this stuff for her. And, boy, it was a real eye opener for her that that's not how I saw my role. We really had to work on that...[she is] really streetwise and, like I said, a survivor. So she was going to take whatever advantage she possibly could, which most of us - the brighter of us- will do anyway... [M y little sister] was very clever - a bright young lady, potentially. W ell, bright period. She had the potential for learning so much, but so much time had passed and so many other habits [had] kind of settled.

Willfully embedding oneself within the social support network of a disadvantaged urban mother necessarily involves subjecting oneself to the fierceness of the "streets" where the young woman lives. There were occasions when the sister-friend made involuntary, direct contact with the violence and hostility frequently associated with lower-class, urban existence. O n such occasions, befriending across social class posed real threats to personal security, and this in turn restricted the sister-friends' ability to render maternal support. In V anessa's case, the threat to personal safety came from the little sister's husband who V anessa characterized as “very, very militant," extremely protective, and suspicious of the relationship his wife had with the new stranger: 
I just felt like he would just as soon cut my throat...you'd walk up and knock on the door and they'd both kind of look at me. It was like [he'd say], "N o, you cannot go anywhere without [me]." So we'd stay there.

V anessa's fear was not simply of a possessive husband's hostility - domineering, hostile husbands exist at all levels of social class - but of the fact that his hostility seemed to reflect the mood of "a lot" of other people who would be at the house when she would come for the young mother. Charlie also felt uneasy about the groups of men she would have to wade through when she went to visit her little sister; the residents were openly resentful of her because they perceived that she was "successful."

Of all the menacing situations identified by the sister-friends, stumbling into illegal drug activity and the violence surrounding it was the most frequently mentioned. F ew of the young mothers connected with the sister-friends were untouched by the proliferating drug culture and drug economy in the city. In retrospect, some volunteers seemed to feel that they should all have been more fearful about entering into their befriending contracts given what knowledge they did have about drug abuse and trafficking among the P roject's constituents and their families. Their obligation to befriend across class thrust them into a world far different than most of them had known:

Loretta: M any times I went to visit and walked in and didn't realize that some of the activity (drug dealing and gun toting) was going on. And I've heard a lot of things. I probably put myself at risk a number of times of being shot and didn't know it. I found out only later... a lot of us ended up, I think, in real precarious 
situations that normally we would not have been in... what I did find was that most people weren't really - in their minds - prepared for the kinds of young women that we were getting - the people who really needed our services, or needed our attention, or needed our time or energy - [who] are most at risk.

Collette (49-year old state criminal justice employee): M y biggest concern was her being in that type of environment and I just wanted to take her out of it...I 'm trying to figure out how I can get her [to live in my duplex] with me. So I just prayed about it and prayed about it, and it just wasn't to be. So I just had to let it go and just call and check on her.

A mong numerous other misfortunes, the pervasiveness of the urban drug problem has waged a vicious assault on the lives of young B lack mothers and on those who want the opportunity to befriend them on their own turf. As Collins (1991) explains, the entire community structure of bloodmothers and othermothers in many inner-city neighborhoods has been eroded by the infiltration of illegal drugs alongside virtually every other aspect of A frican-A merican community life.

The fulfillment of the promise of Black activist mothering and the normative empathy that motivates it is evidenced by the successful placement of middle-class women volunteers within the maternal support networks of disadvantaged young mothers at the B irthing Project. Sister-friends engage in a wide range of maternal care activities that promote strong possibilities for good physical and psychosocial health and social mobility for the young mothers, their 
children, and their families and great emotional satisfaction for the volunteers. O $\mathrm{f}$ the 19 sister-friends who took part in this study, all were sure that at least one word of advice, one act of assistance with prenatal care, or a single provision of some much needed material good had helped to better prepare their young mother for a healthy delivery and first year of mothering. The P roject boasts that only one infant death to a little sister has occurred in the P roject's history. Except for noting the quality of infant's health at birth, no consistent, official follow-up on the little sisters was conducted at the P roject, but about one-half of the sister-friends reported that they had maintained contact with the mothers and their children one to five years or more after delivery. In these cases, both mother and children appeared to highly value the maternal relationship and to have incorporated the sister-friends to some degree into their familial network. The Project's evaluation is that it is highly likely that a long-term, positive effect was made in the lives of these families.

Yet even as maternal needs and race/gender/class obligations appear to be successfully met in a good many instances, there are obvious threats to the continued success of befriending across class. The reports from four of the sister-friends were more heavily laced with negativity and frustration than with satisfaction; and only one sister-friend appeared to be completely satisfied with the befriending experience she had. Like Charlie, whose exasperation about the deteriorating conditions of the urban poor is heard throughout this analysis, many have grown weary of the growing, inescapable violence and hostility of the city. D rugs and other related urban menaces contribute to the widening gap between social class groups in the Black community, a schism based both on real and perceived observations of difference. 


\section{CONCLUSION}

This study sought to broaden an understanding of the tradition, nature, and significance of social class among B lack, maternal activist women by employing the notion of normative empathy. The sister-friends of the Birthing P roject share a concern for the plight of young, disadvantaged urban mothers and their children with their foremothers -- the B lack clubwomen of the late 19th and early-twentieth centuries -- who were equally conscious of the fact that their relative social progress separated them from the masses of Black women and obligated them to play a significant role in relieving the strain on Black urban mothers' lives.

In modern times, however, the social dislocation of middleclass women from lower-class women has sharply increased, and the quality of life among the urban "underclass" mothers has rapidly deteriorated. The effort to "uplift" the race has been undermined by an increasing divergence of experiences, resources, and interests in the Black community along class lines. This divergence is realized for today's B lack maternal activists, like the sister-friends at the Birthing Project, in the "burn-out" they suffer in trying to meet the demands of upwardly mobile work, family and community life; in the differentiated "street wisdom" exhibited by lower-class versus middle-class B lack women that fosters resentment between them around issues of materialism, opportunism, and trust; and, most importantly, in their fear of, and frustration with, drugs and drug-related crime that is too often associated with urban Black existence. Though first-hand observation of the historical documents generated by Black clubwomen is necessary for conclusiveness on this point, cross-class experiences to maintain gender/ethnic solidarity, such as those attempted through the Birthing P roject, are much more difficult today than they were for 
early B lack clubwomen.

In effect, the sister-friends' expressions of disillusionment about the delivery of cross-class support make a strong critique of the lower class and lack of reverence for B lack motherhood and for cross-class maternal cooperation. Reports of little sisters "too needy" for the level of support the volunteers were willing to give appear to be an indictment of the mothers and not, perhaps, of the volunteers' unrealistic expectations. The volunteers' upward mobility from disadvantage seems to be insignificant in the development of a close sisterhood with young mothers who encounter them now as the "other" class of B lack women. F urthermore, helping to empower the young mothers through assistance with arranging intra-class cooperation and support was never mentioned; preoccupation on the part of the volunteers with lifting them up diverted attention from the possibilities for empowering the young mothers to collectively chart their own course for success through intra-class cooperation. T ogether, these observations suggest that normative empathy among contemporary middle-class B lack women might be no more effective in alleviating the problems of the underclass than the benevolence of well-meaning middle-class white women. Systematic study of the sister-friends' practices over a longer period of time would provide for a more complete analysis of the Project's successes and failures. Such a research effort would be greatly enhanced by data from the lower-class young women for whom these practices are intended on their views of normative empathy and their perceptions and experiences with middle class maternal activism.

$\mathrm{N}$ onetheless, the fact alone that contemporary maternal activists are willing to accept the difficult challenge of offering support to underprivileged urban mothers under these conditions 
calls into question the claim that self-interested middle-class B lacks have retreated from the inner city. The mere existence of the B irthing P roject demonstrates that the analysis of B lack middle-class flight fails to recognize that many members of the middle class are attempting to transcend the social class gap. The work and experience of Project women strongly suggests that while class consciousness may be strong among B lack women, gender/ethnic solidarity also remains strong.

I have proposed that activist mothering of this sort is best explained by a strong sense of normative empathy that historically has been shared among B lack women, particularly those of relative privilege. Their consciousness and experiences as B lack women bind them to one another, and their privileged status as upwardly mobile women compounds their sense of obligation to the disadvantaged. Thus, this study re-emphasizes the significance of race, gender, and class in the socialization and political interaction of urban Black women.

F inally, I believe that the evidence of class tension supports a view of cross-class social support that de-romanticizes support relationships and exposes the often unforeseen realities of providing support under difficult social conditions (Cramer and M CD onald 1996). Social support providers are frequently subject to inflated expectations and may suffer emotionally when support arrangements fail to produce the results intended. In the case of the Birthing P roject sister-friends, for instance, the expectations were sometimes inflated by the ideals of gender/ethnic solidarity and B lack activist mothering. Therefore, I am committed to further research that helps determine the extent to which continued and increased urban social class tension threatens the survival of normative empathy and Black maternal activism as traditional, gender/ethnic-specific 
tools of community resistance and self-preservation. 


\section{NOTES}

1. In citing Troester (1984) and Collins (1987), James (1993) defines "othermothers" as "...those who assist blood mothers in the responsibilities of child care... They can be, but are not confined to, such blood relatives as grandmothers, sisters, aunts, cousins or supportive fictive kin.

2. The Project originally discouraged cross-cultural matches, specifically the placing of white volunteers with B lack young mothers. Recently, it has expanded to incorporate the needs of young mothers of other ethnicities, but the focus remains on recruiting and training African-American sister-friends and on the preservation of B lack life and tradition.

3. F rom unpublished speech (1897). F irst presidential address to the $\mathrm{N}$ ational Association of Colored Women; reprinted in Jones (1990), 133-138.

4. "Little sisters" are the P roject's clients; the use of the title "clients" is discouraged because it unduly stresses a hierarchical relationship. In actuality, "little sisters" range in age from 14 to 44 , but the title is used most often in referring to those under 30 .

5. To date, the Project estimates that approximately 3,000 sister-friends have been trained nation-wide.

6. By World War I, the N ational A ssociation of Colored W omen (N ACW) -- the product of a club merger -- had grown to 50,000 members in twenty-eight federations and over one thousand clubs; hundreds of other clubwomen were members of clubs that did not join the N ACW. It is highly probable that because so much of the published scholarship on the B lack Women's Club M ovement has been narrowly focused on the creation of the most 
formal and nationally oriented federations of clubwomen, there is a biased view of the movement as being one purely developed and directed by the middle class. Generally, where the middle-class activist women organized clubs (the least prevalent and most secular form of B lack women's organization), the working-class women were more likely to arrange mutual aid programs and the poor women were highly concentrated within church organizations (Gordon 1994; S cott 1990).

7. Burroughs, N ational B aptist U nion, 192, 208, 289. 


\section{REFERENCES}

Anderson, Elijah. 1990. Streetwise. Chicago: The University of Chicago Press.

Baca Zinn, M axine. 1990. Family, race, and poverty in the eighties. In Black

Women in America, edited by M icheline R. M alson et al. Chicago: The University of Chicago Press.

Benjamin, Lois. 1991. The Black elite: Facing the color line in the twilight of the twentieth century. Chicago: Nelson-H all Publishers.

Boone, M argaret S. 1989. Capital crime: Black infant mortality in America. N ewbury Park: Sage Publications.

Boris, Eileen. 1993. The power of motherhood: Black and white activist women redefine the 'political'. In $M$ others of a new world: $M$ aternalist politics and the origins of welfare states, edited by Seth Koven and Sonya M ichel. N ew York: Routledge.

Christian, Barbara. 1985. Black feminist criticism: Perspectives on Black women writers. N ew York: Pergamon.

Collins, Patricia Hill. 1987. The meaning of motherhood in Black culture and Black mother/daughter relationships. Sage: A Scholarly Journal of Black W omen 4:2-10.

-----1991. Black feminist thought: Knowledge, consciousness, and the politics 
of empowerment. $\mathrm{N}$ ew York: Routledge.

Cramer, James C., and Katrina Bell M cD onald. 1996. Kin support and family stress: $\quad$ Two sides to early childbearing and support networks. $\underline{\text { Human }}$ Organization 55:160-169.

Dawson, M ichael C. 1994. Behind the mule: Race and class in African-American politics. Princeton, NJ: Princeton University Press.

Dickerson, Bette J. 1994. Ethnic identity and feminism: Views from leaders of

African American women's associations. In Color, class and country: Experiences of gender, edited by G. Young and B. Dickerson. London: Zed Books.

DuBois, W .E.B. 1939. The gift of Black folk: The negroes in the making of America. N ew York: W ashington Square Press.

Feagin, Joe R., and M elvin P. Sikes. 1994. Living with racism: The Black middle-class experience. Boston: Beacon Press.

Fullilove, M indy Thompson. 1993. M inority women: Ecological setting and intercultural dialogue. In Psychological aspects of women's health care: The interface between psychiatry and obstetrics and gynecology, edited by D. Stewart and N. Stotland. W ashington, D.C.: American Psychiatric Press. 
Gaines, Kevin K. 1996. Uplifting the race: Black leadership, politics, and culture in the twentieth century. Chapel Hill: University of N orth Carolina Press.

Giddings, Paula A. 1984. When and where I enter: The impact of Black women on race and sex in America. N ew York: William M orrow \& Company.

Gilkes, Cheryl Townsend. 1983. Going up for the oppressed: The career mobility of Black women community workers. Journal of Social Issues 39:115-139.

-----1988. Building in many places: Multiple commitments and ideologies in Black women's community work. In Women and the politics of empowerment, edited by A. Bookman and S. M orgen. Philadelphia: Temple University Press.

---- 1989. Dual heroisms and double burdens: Interpreting Afro-America women's experience and history. Feminist Studies 15:573-90.

Gordon, Linda. 1994. Pitied but not entitled: Single mothers and the history of

welfare, 1890-1935. N ew York: The Free Press.

Hamilton, Tullia Kay Brown. 1978. The N ational Association of Colored W omen, 1896-1920. Ph.D. diss., Emory U niversity, Atlanta.

Harley, Sharm and Rosalyn Terborg-Penn. 1978. The Afro-American woman:

Struggles and images. Port W ashington, NY: Kennikat Press.

Henderson, Karla A. 1984. W omen as volunteers. The Humanist, July/August. 
Higginbotham, Evelyn Brooks. 1993. Righteous discontent: The women's

movement in the Black Baptist church, 1880-1920. Cambridge: Harvard University Press.

Higginbotham, Elizabeth, and Lynn W eber. 1992. M oving up with kin and community: $\quad$ Upward social mobility for Black and white women. Gender \& Society 6:416-40.

Hine, D. Clark. 1990. "We specialize in the wholly impossible": The philanthropic work of Black women. In Lady bountiful revisited: Women, philanthropy, and power, edited by K.D. M cCarthy. New Brunswick, NJ: Rutgers U niversity Press.

James, Stanlie M . 1993. M othering: A possible Black feminist link to social transformations? In Theorizing Black feminisms: The visionary pragmatisms of Black women, edited by S. James and A. Busia. London: Routledge. Jenkins, M aude Thomas. 1984. The history of the Black woman's movement in America. Ph.D. diss., Columbia U niversity Teacher's College. Jones, Beverly W ashington. 1990. The life and writings of M ary Eliza Church Terrell, $\quad$ 1863-1954. N ew York: Carlson. Jones, Jacqueline. 1985. Labor of love, labor of sorrow: Black women, work, and the family from slavery to the present. N ew York: Basic Books. J oseph, Gloria I., and Jill Lewis. 1981._Common differences: Conflicts in Black and 
white feminist perspectives. Boston: South End Press.

Ladner, Joyce. 1986. Black women face the 21st century: M ajor issues and problems. The Black Scholar 17:12-19.

Landry, Bart. 1987. The new black middle class. Berkeley: University of California Press.

Lawson, Bill. 1992. U plifting the race: M iddle-class Blacks and the truly disadvantaged. In The underclass question, edited by B. Lawson. Philadelphia: Temple U niversity Press.

Lerner, Gerda. 1974. Early community work of Black club women. Journal of N egro History 56:158-167.

M artin, Joanne M., and Elmer P. M artin. 1985. The helping tradition in the Black family and community. Silver Spring, MD: National Association of Social Workers.

M athews, H olly F. 1992. Killing the medical self-help tradition among African

Americans. In African Americans in the South: Issues of race, class, and gender, edited by $\mathrm{H}$. Baer and $\mathrm{Y}$. Jones. Athens, GA: The University of Georgia Press.

M cD onald, Katrina Bell. 1995. Sister-friends: Re-creating maternal support in the 
African- American community. Ph.D. diss., University of California, Davis.

M ontada, Leo, and Hans W erner Bierhoff. 1991. Studying prosocial behavior in

social systems. In Altruism in social systems, edited by L. M ontada and H.W. Bierhoff. Toronto: Hogrefe \& Huber.

M orgen, Sandra. 1988. "It's the whole power of the city against us!": The development of political consciousness in a women's health care coalition. In W omen and the politics of empowerment, edited by A. Bookman and S. M orgen. Philadel phia: Temple U niversity Press.

M orgen, Sandra, and Ann Bookman. 1988. Rethinking women and politics: An introductory essay. In W omen and the politics of empowerment, edited by A. Bookman and S. M orgen. Philadel phia: Temple University Press.

Naples, N ancy A. 1991. "Just what needed to be done": The political practice of women community workers in low-income neighborhoods. Gender \& Society $5: 478-494$.

-----1992. Activist mothering: Cross-generational continuity in the community work of women from low-income urban neighborhoods. Gender \& Society 6:441-463.

N everdon-M orton, Cynthia. 1989. Afro-American women of the South and the

advancement of the race, 1895-1925. Knoxville: U niversity of Tennessee 
Press.

Peterson, Elizabeth A. 1992. African American women: A study of will and success.

Jefferson, ND: M cFarland \& Company, Inc.

Rodgers-Rose, La Frances. 1980. The Black woman: A historical overview. In The

Black woman, edited by L. Rodgers-Rose. Beverly Hills: Sage.

Rowley, Diane. L., Carol J.R. Hogue, Cheryl A. Blackmore, Cynthia D. Ferre, Kendra Hatfield-Timajchy, Priscilla Branch, and Hani K. Atrash. 1993. Preterm

delivery among African-American women: A research strategy. In $\underline{\text { Racial }}$ differences in preterm delivery: Developing a new research paradigm, edited by

D. Rowley and H. Tosteson. American Journal of Preventive M edicine

9(suppl):1-6.

Scott, Anne Firor. 1990. M ost invisible of all: Black women's voluntary

associations. The Lournal of Southern History 56:3-22.

Shaw, Stephanie. 1991. Black club women and the creation of the $\mathrm{N}$ ational

Association of Colored W omen. Journal of W omen's History 3:10-25.

Singh, Gopal, and Stella M. Yu. 1995. Infant mortality in the U nited States:

Trends, differentials, and projections, 1950 through 2010. American Journal of

Public Health 85:957-964.

Sudarkasa, Niara. 1988. Interpreting the African heritage in Afro-American family organization. In Black families, edited by H. P. M cAdoo. N ewbury 
Park: Sage.

Townes, Emilie M aureen. 1993. Womanist justice, womanist hope. Atlanta, GA: Scholars Press.

Troester, Rosalie Reigle. 1984. Turbulence and tenderness: M others, daughters, and "othermothers" in Paule M arshall's Brown girl, brownstones. Sage: A Scholarly Journal on Black Women, 1:13-16.

W ilson, W illiam J. 1980. The declining significance of race: Blacks and changing American institutions. Chicago: U niversity of Chicago Press.

----1987. The truly disadvantaged: The inner city, the underclass, and public policy. Chicago: University of Chicago Press.

----1989. The underclass: Issues, perspectives, and public policy. The Annals of the American Academy of Political and Social Science 501:182-92.

W ood, Julia T. 1994. Who cares? Women, care, and culture. Carbondale: Southern Illinois University Press. 
AUTH OR'S N OTE: This research was supported by grants from the A merican Sociological Association M inority F ellowship P rogram, the U niversity of California M inority Dissertation F ellowship P rogram, and the California S tate U niversity D octoral Incentive P rogram. A special debt is owed to Kathryn $\mathrm{H}$ all, B renda M itchell and the other participants at The Birthing P roject. I am grateful to James Cramer, Carole Joffee, Patricia T urner, A ndrew Cherlin, and Toby Ditz for their comments on earlier versions of this article and on-going support. Katherine $V$ aast and E stelle Y oung also lent invaluable research assistance to this project. 